\title{
Anlatıcı Sorunsalı
}

\section{DOÇ. DR. OKTAY YIVLI*}

\section{Öz}

Her cinsten anlatının öyküsellik ve anlatısallık olmak üzere iki düzlemi vardır. Öyküselliğin anlatısallık tarafından aktarılmasını anlatıcı figürü yerine getirir. Dünden bugüne anlatıcı kavramı çevresinde değişimler olmuş ve bu devinime bağlı olarak anlatıbilimde farklı paradigmalar ortaya çıkmıştır. Bu konudaki belli başlı değer dizilerini gramatikal, epistemolojik, eklektik, yapısalcı ve edimsel kaynaklı tipolojiler oluşturur. İlkinde dil bilgisi referans alınmıştır. Epistemolojik tipoloji anlatıcıların bilme derecelerine yaslanır. Eklektik olan seçmeci bir tutumla farklı parametreleri kullanır. Yapısalcı tipoloji meşruiyetini işlevden alır. Edimsel olan ise deneyim alanından ve deneyimin niteliğinden hareket eder. Bunların bir kısmı tarihsel karakter taşıdığı için yeni anlatılara çözüm bulmaktan uzaktır. Çağdaş tipolojiler ise birbirinden farklı olguları kavramlaştırmaktadır. Nihai olarak çeşitlenen anlatma aygıtlarının anlatıcıya farklı olanaklar sunduğu muhakkaktır.

Anahtar sözcükler: anlatıcı, anlatı, kurmaca, anlatıcı paradigmaları, anlatıcı tipolojileri

\section{THE NARRATOR PROBLEMATIC}

\section{Abstract}

There are two planes in every kind of narrative: -narrativity diegesis-. Diegesis, which is conveyed via narration, is performed by the narrative figure. The -role? of narrator has not remained the same - throughout history, and thus different paradigms have emerged in narratology due to this diversity. Grammatical, epistemological, eclectic, structuralist and operantbased typologies form the main value sequences on this subject. In the first one, grammar is taken as reference. Epistemological typology depends on the degree of knowledge of the narrator. The eclectic one uses different parameters with a selective attitude. Structuralist typology takes its legitimacy from function. The operant one is based on the field of experience and the quality of the experience. Because of their historical character, some of these typologies are not capable of offering solutions to contemporary narratives, which may conceptualize alternative facts. Contemporary typologies conceptualize different phenomenon. In conclusion, admittedly various devices provide the narrator with different possibilities of expression.

Keywords: narrator, narrative, fiction, narrator paradigms, narrator typologies

\footnotetext{
* Muğla Sıtkı Koçman Ün. Edebiyat Fak. TDE Bölümü, oktayyivli@hotmail.com, orcid.org/0000-0003-4129-1193 Gönderim tarihi: 30.04.2020 Kabul tarihi: 23.05.2020

Bu makaleyi, öne sürdüğüm düşünceleri akademik ortama taşımak amacıyla popüler edebiyat dergisi Muhayyel'de yayımladığım "Anlatı ve Anlatan Ses" adlı iki parçalı yazıdan yararlanarak hazırladım.
} 


\section{Gíriş}

$\mathrm{O}$ lgusal ya da değil, sözcüğün kök anlamına gönderme yapan her türden anlatı, öyküsellik ve anlatısallık olmak üzere iki düzlemden oluşur. Öyküsellik, belli bir zaman-uzamı kapsayan estetik ya da gerçek bir deneyim, bir tanıklık alanını; anlatısallık ise bu deneyimin/tanıklığın biri tarafından başka birilerine söz-edim yoluyla aktarılmasını gerektirir. Bu iki alan bir bakıma anlatının önkoşuludur.

Yapılan tanımlamadan fark edilebileceği gibi anlatının, biri olguya dayanan diğeri kurmaca olmak üzere iki çeşidi vardır. İnsan dünyasında gerçekleşen yaşantılarla buna eşlik eden seyir, tarihsel özneler tarafından sözlü ya da yazılı olarak ötekilere anlatıldığı andan itibaren gerçek anlatı tezahür eder. Kurulmaya, düzenlenmeye, eksiltmeye uğrasalar da göndergelerinin reel olduğunu kabul ederiz ve bu metinlere uygulanacak her türlü sahihlik işlemini meşru sayarız. Kurmaca anlatının olgusal olandan farkıysa diğerinde sahiden bulunan deneyimin/tanıklığın kötüye kullanılmasıdır. Bu ikincisi, hikâyesini kurarken tarihsel olayları ele alsa da yapıbozumuna uğratmakta, sahte olgular yaratmakta, namevcut yaşam kesitlerini varmış gibi göstermektedir. Bütün bu yapıntı karakterine karşın miyarı, yalan/gerçek değil inşa ettiği evren bağlamında tutarlı olup olmadığıdır.

Aktüel bir zaman birimi ya da dizisinde gerçekleşebileceğine göre öyküselliğin, varsayımsal olarak şimdide geçtiğini düşünebiliriz. Oysa anlatısallık geçmiş, şimdi ve gelecek referansına ayrı ayrı ya da bir arada sahip olabilir. Bununla birlikte kökeni dramaya uzanan az sayıdaki eşzamanlı öykülemeler -anlatısallığın sıfır derecesi- hariç, sona eklenen bir biçimbirimle (-DI) ilgili zaman kiplerinin hepsi, uzak ya da yakın belli bir geçmişe gönderilir. O hâlde anlatısallığı, öyküselliğin barındırdığı olgusal ya da sözde olgusal şimdi'nin mutlak geçmiş'e çevrilmesi olarak tanımlayabiliriz. Bu bağlamda sözü edilen mutlaklık; anlatısallığın, hiçbir geçmiş ifadesi taşımasa bile hikâyeyi -anlatının doğasına uygun şekilde- koşulsuzca bir geçmişe yerleştirmesi anlamına gelir.

Yapısal anlatı biliminden alınan motivasyonla dikkat bütünüyle anlatısallığa yöneltildiğinde bu düzlemde ilkin üç bileşen ayırt edilir: anlatıcı, metin ve okur. Sırasıyla bu kavramlar, performans bağlamında gerçek özneye, sözlü söyleme ve canlı dinleyiciye; matbu olan söz konusuysa ses imgesine, yazılı söyleme ve örtük ya da açık okura karşılık gelecektir. Asıl işin klasik basım ya da elektronik yolla çoğaltılan kurmaca anlatı olduğu anımsandığında ses imgesi üstünde yoğunlaşmak gerektiği anlaşılacaktır.

Kural dışılıklar bir yana, öyküsel olanın biri tarafından muhataba aktarılması gerektiğine göre anlatıcının, diğer bir ifadeyle anlatan sesin varlığı, anlatmaya dayalı metinler için ontolojik bir zorunluluktur. Bir ucu öyküsellikte bulunan metnin okura ulaştırılması böylece mümkün hâle gelecektir. Bir "beden"e sahip olsun ya da olmasın anlatıcı bileşeni, yazılı ortamda her zaman bir ses, imgesel bir ses olarak ortaya çıkar. Kimi zaman merkezî karakterle bütünleşip türdeş bir figür olarak deneyim, kimileyin hikâye kahramanından ayrılıp türdeş olmayan bir figür şeklinde tanıklık alanında görünür. Kimi durumlarda ise bu tanıklık, türdeş olmayanı aşıp doğrudan metin tarafından üstlenilir. 
Gerçek yazarın okurda uyandırmak istediği etki, her yapıt için yeniden yürürlüğe giren anlatısal stratejiler ve ilgili anlatıdaki öyküselliğin doğası anlatıcı tipinin seçimini belirleyecektir. Yazınsal uzlaşıma bağlı olarak elinin altındaki "alet kutusu"ndan doğal bir refleksle bir anlatıcı konseptini seçmekle yazarın görevinin tamamlandığı yerde eleştirmenin/çözümlemecinin sorunsalı başlar. Anlatı sesi bağlamında araştırma öznesinin sorduğu soru şudur: Yazarın aldığı inisiyatifi, yapılan seçim üzerinden anlatmanın kazandığı nüansı hangi tipoloji, hangi anlatıcı kuramı kusursuz şekilde açılayabilir?

\section{TIPOLOJILERIN BETIMLENMESİ}

Geleneksel anlatı çalışmalarından yapısalcılığa, oradan yapısalcılık sonrasına uzanan zaman boyunca kurmaca anlatılardaki anlatan ses, farklı kuramsal çerçevelerle sunulmuş; eksik kalan anlamsal gedikleri doldurmak niyetiyle aynı olguyu karşılamak üzere birbirinin ardı sıra farklı değer dizileri öne sürülmüştür.

Bunların hiçbirinde düşüncenin konusu değişmemiş, anlatısallık adı verilen aynı alan içinde tezahür eden anlatıcı, ince bir anlam parçasının ve ayrıntıcı bir dikkatin peşinde olmak üzere yeniden tanımlanmıştır. Şimdi geçmişten bugüne önerilen ve kullanılan bu diziler yaslandıkları ölçütten ya da doğalarından hareketle betimlenecektir.

\subsection{Gramatikal tipoloji}

Yapısal anlatıbilim öncesinde ortaya çıkan ve dil bilgisini referans alan bu tipoloji, anlatma sirasinda kullanilan adillardan hareket edilerek düzenlenmiştir. Tek bir düzeyde beliren ve sacayağı oluşturan paradigma; birinci kişi anlatıcı, ikinci kişi anlatıcı ve üçüncü kişi anlatıcıdan ibarettir. Birinci kişili anlatı, seçtiği "ben” zamiriyle hikâye uzamında bedenlenen bir figüre işaret eder. Oysa diğer anlatıcı tipleri için aynı durum geçerli değildir. İkinci kişi, farklı anlatılarda ya da aynı anlatının farklı

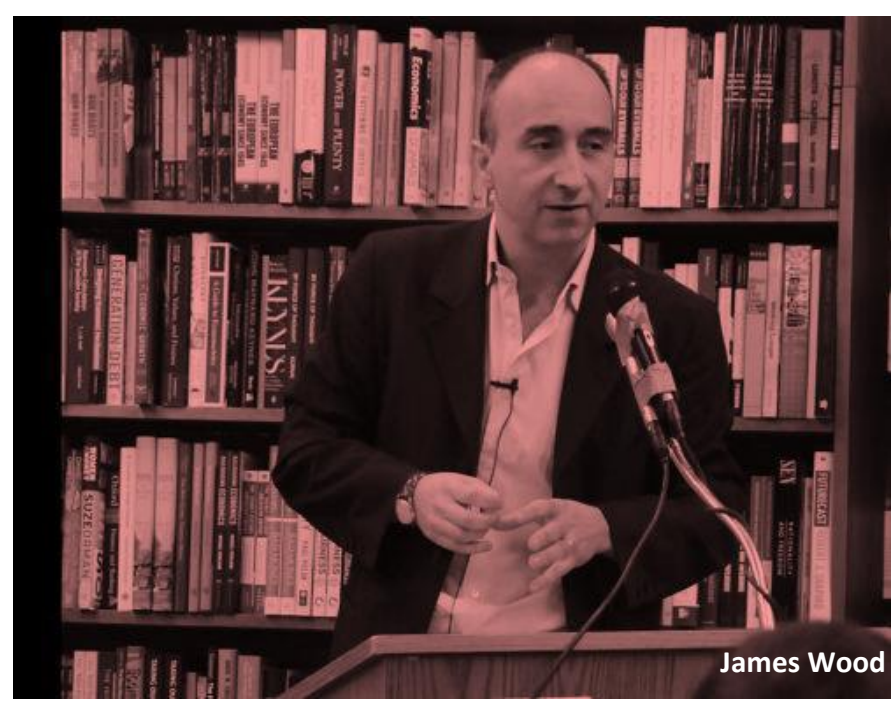
kısımlarında hem türdeş hem türdeş-olmayan şeklinde ortaya çıkabileceği için “sen” adılı, kimi zaman anlatmakta olanın kendisine kimileyin de anlatı içindeki herhangi bir karaktere yönelebilir. Üçüncü kişili anlatımda kullanılan "o" zamiri ise anlatıcıyı değil daima hikâyesi anlatılana gönderme yapar. Batı'da James Wood'un (2013) Kurmaca Nasıl İşler çalışması ile Türk edebiyatında Mehmet Tekin'in (2002) Roman Sanatı bu sinıflandırmayı esas alarak kurmaca çözümlemesi önerisinde bulunur. 


\subsection{Epistemolojik kökenli tipoloji}

Yapısalcılık öncesi döneme denk gelen ve bugünden geriye bakıldığında geleneksel bir nitelik taşıyan bu kategorizasyon, anlatıcıları hikâye dünyasını bilme derecelerine göre tanımlar. Farklı kuramsal metinlerde başka adlar alabildiğinden çeşitli türevleri bulunan bu sınıflandırmayı Türk edebiyatında, Şerif Aktaş'ın (2000) hazırladığı Roman Sanatı ve Roman İncelemesine Giriş kitabı temsil etmektedir. En geniş ve mutlak bilme hâlinden en az ve ampirik olarak bilmeye doğru daralan bir yelpazede anlatan ses; "hâkim anlatıcı" (tanrısal, omniscient), "müşahit anlatıcı" ve "kahraman anlatıcı" şeklinde sıralanır. Aynı kaynak, yazarın dilini üstlenmiş kabul ettiği için ilk tipten "yazar-anlatıcı" diye söz eder.

\subsection{Eklektik tipoloji}

Ses imgesini kategorize ederken ötekilerde olduğu üzere tek bir ilkeden hareket etmeyip birden fazla parametreye yaslanan tipolojiler bulunmaktadır. Nurullah Çetin (2007) tarafından Roman Çözümleme Yöntemi'nde öne sürülen ve özellikle kurmaca anlatı üstüne yapılan tez çalışmalarında fazlaca yararlanılan dizi, bu cinstendir. Adı geçen öneride anlatıcılar "gözlemci" (observer-narrator), “özne" ve "çoğul" olarak yine üçlü şematik bir yapıyla ortaya konur. Gözlemci anlatıcı "nesnel tutumlu", "öznel tutumlu" ve "tanrısal konumlu" olmak üzere üçe ayrılır. Nesnel tutumlu anlatıcı, kişilerin iç dünyalarından haberli değildir. Öznel tutumlu olan olayları, karakterlerden birinin zihninden aktarır. Tanrısal konumlu (omniscient) anlatıcı ise her şeyi bilmektedir. Özne anlatıcı, olayın hem yapıcısı hem de anlatıcısı olarak sunulduktan sonra “özdeş özne" ve "ayrışmış özne" terimleriyle ikiye bölünür. Günlük formuyla düzenlenen anlatılarda görülen, aktaran ile aktarılan arasında tam bir örtüşmenin olduğu anlatıcı “özdeş”tir. Anımsamalarla kurulan anlatılarda beliren ve aktaran ile aktarılanın ikiye bölündüğü anlatıcı ise "ayrışmış"tır. Pek çok anlatı kişisinin kendini anlatması ya da anlatıda birden çok anlatıcı tipine yer verilmesi ise çoğul anlatıcıyı oluşturmaktadır. Bu kuramsal düşünmedeki seçmeci tutum, önce bilme durumuna vurgu yaparken ardından nicel bir ölçüte kaymış olmasıdır. Tipolojideki ilk iki anlatıcı tipi bir çeşit epistemeden elde edilmişken sonuncusu azlık/çokluk durumu üstüne kurulur.

\subsection{Yapisalcı tipoloji}

Fransız anlatı bilimci Genette (2011) anlatıcı konusunu, Anlatının Söylemi yapıtının "ses" bölümünde ele alır. İlkin anlatı düzeylerinden söz eder ve kurmacada saptadığı üç düzeyi, vatandaşı Abbe Prevost'un Mémoires kitabı üzerinden betimler. Kurmaca yazar M. de Renoncourt'un yazma süreci ona göre birinci düzeyde gerçekleşen diş-öyküsel (ekstradiegetik) bir yazınsal edimdir. Anlatının içindeki olaylar ve hikâye kahramanın anlatımı öyküsel (diegetik) ya da iç-öyküseldir (intradiegetik). İç-öyküsel yapı içine yerleştirilmiş olası bir karakter anlatısına ise üst-öyküsel (metadiegetik) adını verir.

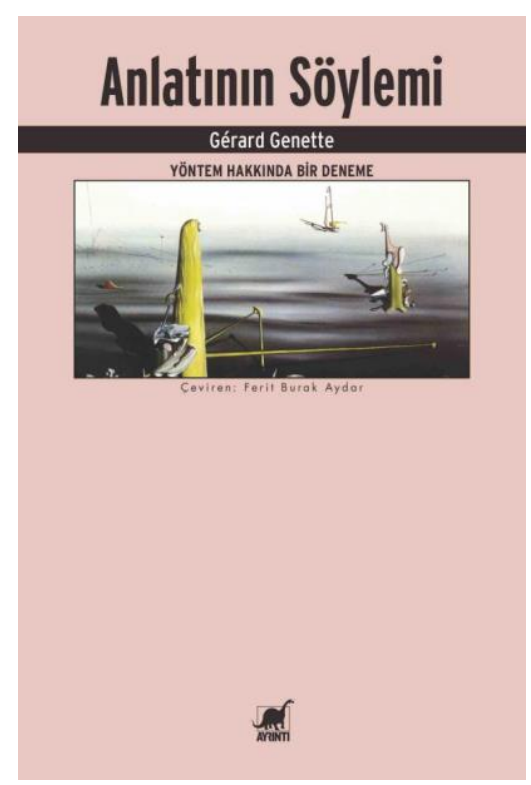


Bunun ardından Genette, anlatı türlerine gönderme yapıp iki tür anlatıyı birbirinden ayırır: Anlatıcının hikâyede bulunmadığı anlatılar, anlatıcının hikâyesinde bir karakter olarak yer aldığı anlatılar. Bunlardan ilkini "heterodiegetik" (dış-anlatıcılı), diğerini "homodiegetik" (iç-anlatıcılı) şeklinde adlandırır. İç-anlatıcılı olanı kendi içinde yine ikiye ayırır: Kahramanın anlatıcı olduğu anlatılar ve anlatıcının tanık ya da gözlemci olduğu anlatılar. Bunlardan ilki için "otodiegetik" (ben-anlatıc1lı) terimini kullanır. Mevzubahis olan anlatıcıları adlandırmaksa Genette'in anlatı türleri için kullandığı terimlerin sıfat eklerinin üstü çizilerek sırasıyla dış-anlatıcı, iç-anlatıcı ve ben-anlatıcı terimleri kullanılabilir.

Genette ilkin düzey, ardından "şahıs" üzerinden anlatıları sınıflandırdıktan sonra anlatıcının dört temel konumunu şöyle tanımlar: 1) Dışöyküsel-dışanlatıcılı dizi: İçinde kendisinin yer almadığı birinci dereceden anlatıcı. 2) Dışöyküsel-içanlatıcılı dizi: Kendi hikâyesini anlatan birinci dereceden anlatıcı. 3) İçöyküsel-dışanlatıcılı dizi: İçinde kendisinin yer almadığı bir hikâye anlatan ikinci dereceden anlatıcı. 4) İçöyküsel-içanlatıcılı dizi: Kendi hikâyesini anlatan ikinci dereceden anlatici.

\subsection{Edimsel kaynaklı tipoloji}

Anlatıbilimsel karakter taşıyan bir başka öneri ise anlatanın aktardığı hikâyede deneyim sahibi olup olmamasına göre sınıflandırma yapar (Yivli, 2016a, s. 495-500). Buna göre anlatıcılar ilkin kavramsal ve deneyimsel olarak iki başlık altında toplanır. Ardından ikincisi itirafçı ve tanık terimleriyle yeniden ayrıştırılır. Kavramsal anlatıcı hikâye dünyasında yer almayıp okur açısından yalnızca kavram olarak, imgesel bir ses olarak mevcutken deneyimsel olan, anlatma işlevinin yanı sıra olayların içinde bulunup anlatıda birincil ya da ikincil bir konum edinir. İtirafçı anlatıcı, anlatının merkezî karakteri durumundadır ve bir anlamda kendi hikâyesini anlatmakla, kendi yaşantısını itiraf etmekle yükümlüdür. Tanık olan ise hikâyede ikincil bir figür olarak yer alıp gördüklerini ve duyduklarını yorumla birleştirerek okura ulaştırır.

\section{PARADİGMLAR TARTIŞMASI}

Gramatikal tipoloji geçmişte yaygın şekilde kullanılmasına, bugünkü çalışmalarda ise kısmi olarak varlığını korumasına karşın öteden beri çeşitli eleştirilere uğramıştır. İlk olarak Genette'in (2011) bu tipolojiye yönelttiği eleştiri anımsanmalıdır. Ünlü edebiyat kuramcısı, adıl kullanımından kaynaklanan çeşitliliği, görüntü düzeyinde bulur. Anlatıcı için hangi zamir tercih edilirse edilsin, bunun gerisinde her zaman birinci kişi yer alacaktır. Öyleyse bu sahte zenginlik "dil bilgisel" bir seçimden ibarettir. Bu itirazın yanı sıra sözü edilen değerler dizisindeki daha esaslı eksiklik, birinci kişi adılını kullanan iki farklı anlatıcının ayırt edilememesi, aksine onların aynı başlık altında bir araya getirilmesidir. Bilindiği gibi anlatısal metinlerde "ben" zamirini kullanan iki tür anlatıcı vardır. Bunlardan biri kahramanı olduğu, diğeri ise tanığı olduğu hikâyenin anlatıcısıdır. Adıl kökenli terminolojiyle hareket edildiğinde farklı anlatısal konumlara sahip iki sesin ayrımı olanaksızlaşmaktadır.

Bir çeşit epistemolojiye dayanan tipolojideki tanrısal nitelikli anlatıcının naif yanı, olmuş olandan olacak olana kadar bütün her şeyi mutlak şekilde bilmesidir. Zira bu özellik Realist 
yazarlar tarafından sorun alanı hâline getirilmiş, uygulamada tipin üstündeki aşırı yetkiler alınarak sınırlı bilme durumuna indirilmiştir. Modern dönemde ilgili tip, ilk belirdiği ve kavramlaştırıldığı şekliyle ayakta kalamadığı için aynı olgudan hareket edilerek üretilen kuramsal zemin de eleştirmenin ayaklarının altından çekilmiştir. Konuştuğumuz bağlam içinde Aktaş tarafından önerilen paradigmada açığa çıkan sorun, bilmenin doğasının dereceli olmasına karşın "hâkim anlatıcı" teriminin seçimiyle birlikte mutlak bilme dışındaki öteki anlatıcı konumlarının temsil edilememesidir. Eğer bu sınıflandırma, "müşahit" terimiyle hem hikâye dünyası dışına yerleşen sınırlı ya da az bilen anlatıcıyı hem de bir figür olarak hikâyede bulunup olaylara tanıklık eden anlatıcıyı karşılayacaksa -bu konuda bir açıklık yoktur- bu kez bir çelişki ortaya çıkacaktır: Farklı kumaşlardan biçilmiş iki anlatısal olgu, bu tipoloji tarafından bir bakıma eşitlenmiş olacaktır. Ayrıca inceleyen öznenin, ilgili terimi her dile getirdiğinde kastının ne olduğu, hangi anlatıcı tipini işaret ettiği belirginleşmeyecektir. Tipolojinin sorunlu bir başka yanı, anlatıcı ile bakış açısı kavramlarını aynı kategori içinde çözümlemek istemesidir. Buradaki hata, iki kavramın aynı figür tarafından üstlenilmesini bir zorunluluk olarak görmektir. Oysa kavram-figür eşleşmesi olumsal bir niteliğe sahiptir: Bakış açısı ve anlatıcı olgularının gerisinde aynı figür yer alabileceği gibi başka figürler de bulunabilir. Türdeşlik durumunda sorun ortaya çıkmazken bakış açısı ve anlatıcı yetkesinin bölünmesi durumunda paradigma çökecektir.

Eklektik tipolojinin getirdiği ilk yenilik, kendinden önceki dizide yer alan "hâkim" ile "müşahit" tiplerini aynı terimle yani "gözlemci anlatıcı" ile ifade etmesidir. Ancak bu yeni olma durumu beraberinde iki sakıncayı getirmektedir. İlk olarak bu kavramsal öneri, hikâyenin içinde ya da dişında olma hâlini ortadan kaldırmakta, bu iki-aradalığın getirdiği inceliklere gözünü kapamaktadır. İkinci sakıncalı durum, “öznel tutumlu gözlemci" adıyla sunulan anlatıcının "ses" alanını terk edip odaklanma alanına girmesi, bir bakıma kategori ihlali yapmasıdır. Yeni dönem anlatıları için tasarlanan bu tipolojinin üstünlüğü, nicel yolla elde edilen "çoğul anlatıcı" tipi sayesinde postmodern anlatı üzerine yapılacak incelemelerde araştırmacıyı yeni bir teknik aygıtla donatmasıdır. Bu tipoloji bağlamında değil postmodern estetik düzeyinde tartışılması gereken mesele ise postmodern metinlerde sahiden ve her durumda birden fazla anlatıcının bulunup bulanmadığı, bunlardan ne kadarının odaklanmayla ne kadarının doğrudan anlatmayla ilgili

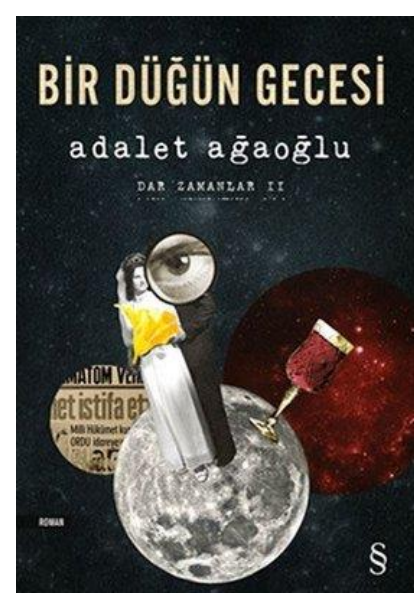
olduğudur. Anlatı nihai olarak tek bir yetkili yoluyla okura ulaştırılacağına göre metinde sesi duyulan pek çok figür sözde anlatıcılık ile malul değil midir? Örneğin Selim İleri'nin (2015) “Türküsüz" ile Necip Tosun'un (2017) “Körebe" öykülerinde ve Adalet Ağaoğlu'nun (2012) Bir Düğün Gecesi ile Orhan Pamuk'un (1996) Sessiz Ev romanlarında duyulan çoğul sesler, ilgili karakterleri özerk anlatıcı mı yapmaktadır yoksa onların bilinçlerini mi sunmaktadır? Eğer ikincisi doğruysa yürürlükte olan, anlatıcı değil bakış açısı meselesi olacaktır. Zira verilen bu örnekler, ses yoluyla değil odaklanma yoluyla ilgili anlatılara zenginlik katmaktadır.

\footnotetext{
* Sözde anlatıcılık kavramıyla ilgili daha geniş bilgiye ulaşmak için şu bildiriye bakılabilir: Oktay Yivli, "Sözde Anlatıcı", Uluslararası Türk Dünyası Ĕ̆itim Bilimleri ve Sosyal Bilimler Kongresi Bildirileri, III. Cilt, Ankara 2016b, s. 495-501.
} 
Yapısalcı etiketle sunulan Genette'in tipolojisi anlatıcının konumunu hem anlatı düzeyiyle hem hikâyeyle olan ilişkisiyle tanımladığı için görece ilk elden bir üstünlük elde etmektedir. Diğer tipolojilerde anlatıcının hangi düzeyde bulunduğu bilgisi gösterilmemiş hatta bu olgu, bir sorunsal olarak saptanmamıştır. Bu dizideki diğer yenilik, sınıflandırmanın anlatıcı-hikâye ilişkisine bakılarak yapılmış olmasıdır. Bu öneri, dil bilgisi kökenli paradigmanın yerine ve onun eksikliklerini giderecek şekilde ikame edilmiş görünmektedir. Tartışmalı yanına gelince ikinci dereceden anlatıları adlandırmak için kullanılan üst-öyküsel teriminin Türkçede belirli bir kafa karışıklığı yaratmasıdır. Belki Fransızca için sorun oluşturmayan, piramit kavramsal-metaforu yoluyla üretilen ve ilkinin üstüne yerleştirilen bu anlatı düzeyine, Türkçede kuyu kavramsalmetaforu kullanılarak alt-öyküsel dense muğlaklık bir nebze giderilebilir. $\mathrm{Bu}$ anlatı düzeyi tipolojisinin kırılgan yanı, ayna efekti (mise en abyme) ya da çerçeveli anlatımın modern modeli ${ }^{*}$ yoluyla iç içe geçirilmiş fazlaca hikâyenin varlığı söz konusu olduğunda "üst-öyküsel" teriminin yetersiz kalacağıdır. Aynı terminolojinin gereksiz şekilde tekrar eden yanı ise anlatıda ikinci düzeyden bir hikâye bulunmasa bile yazarın konumunu ifade etmek için çalıştırılmasıdır. İlgili kaynakta Homeros için kullanılan "dışöyküsel-dışanlatıcı" tanımlaması buna örnektir. Oysa bu, daha baştan verili bir bilgidir: Her anlatı nihai olarak gerçek/tarihsel bir yazar tarafından üretilir.

Anlatı bilimsel karakter taşıyan edimsel kaynaklı tipoloji, anlatıcının hikâyeyle ilişkisini ilkin eylem parametresiyle sınamakta, ardından anlatma için seçilen ses tonunun, öznellik/nesnellik bilgisini araştırmaktadır. Hikâyeyi aktarmak için kavramsal anlatıcı seçilmişse nesnel, deneyim sahibi anlatıcı seçilmişse öznel bir tonun kendiliğinden ortaya çıkacağı var sayılmaktadır. Deneyimsel anlatıcının ikiye bölünmesinden elde edilen itirafçı ile tanık ise hem olayların ne şekilde deneyimlendiğini gösterecek hem de yazarın mesafe kontrolü ve okurda bırakmak istediği etki, bu terminoloji üstünden izlenebilecektir. Tanığın seçildiği durumlarda mesafenin artırıldığı ve olayların bir filtreden geçirildiği, itirafçının seçildiği durumlarda mesafenin neredeyse ortadan kalktı̆̆ı, buna karşın okuru yönlendirecek herhangi bir mekanizmanın kalmadığı fark edilir. Bu değer dizisinin eksik yanı, anlatısal düzlem bakımından anlatıcıyı konumlandırmamasıdır. Saptanan kusur, çok düzeylilik henüz ortaya çıkmadan kategorik olarak değil, çok düzeyliliğin çıktığ1 her durumda derecelendirmeye gidilerek çözümlenebilir. Hikâye içinde hikâyenin ilk görüldüğü yerde, hangi cinsten olduğuna bakılmaksızın anlatıcı tipinin önüne getirilecek ikinci derece, -iç içe geçen hikâyelerin devamı hâlinde- üçüncü derece, dördüncü derece terimleri anlatıcı-düzey ilişkisini açıklayabilecektir.

\section{MODELLERİN İMKÂNLARI}

Bu kısımda, seçilen herhangi bir paradigmada yer alan anlatıcı modellerinin yazarlara sağladı̆̆ı olanaklar ve kısıtlar inceleme konusu yapılacak; bunun için aynı anda son iki tipolojiye göndermede bulunularak çalışma, örnekler üzerinden yürütülecektir. Diştan içe doğru ya da kavram alanından deneyim alanına doğru ilerleyerek imkânlar araştırılmaya başlanacaktır.

\footnotetext{
* Çerçeveli anlatımın modern modeli konusunda ayrıntılı bilgi için bakınız: Oktay Yivli, “Yiğit Bener'den Böcek Öyküleri", Türük, S. 11, Aralık 2017, s. 68-76.
} 
"Bomba", "Kulak Tıkaçları" ile "Çark" öykülerini aktarmak üzere diş-anlatıcı, bir başka deyişle kavramsal anlatıcı seçilmiştir. Aynı modelden elde edildiği hâlde bu anlatıcılar, odaklanma ve bilme kapasitelerinin farklılığı üzerinden ilgili metinlerde farklı tonlar kazanmışlardır. Ömer Seyfettin'in (1992) "Bomba" anlatısının başında yer alan betimlemeden anlatıcının, figüral -hikâye figürlerinden biri- olup olmadığı hemen anlaşılmaz (s. 125-147). Anlatıcının tipi ve konumu ancak Boris'in portresi verilirken ve büyük bir ustalıkla erkek karakterin geçmişi ayrıntılarla okura sunulurken fark edilir. Olimpik konumla ilgili bir başka ayrıntı, yeni sahneye girmişken aktüel zamanda yapılan gözlemle değil, geçmişten gelen mutlak bir bilgiyle Baba İstoyan'ın alışkanlıklarının bilinmesidir. Anlatıcı, okur karşısındaki otoritesini "değişken" odaklanma yardımıyla Magda, Boris ve Babanın zihinlerine girip çıkarak iyice pekiştirir. Her ne kadar bu durum, anlatma sesinden çok odaklanma sorunu olsa da zihinleri bir an için yüksek 1şık altında gösteren pratikler, anlatıcının hikâye üstündeki kontrolünü artırır.

Ağaoğlu'nun (2015, s. 163-171) "Kulak Tıkaçları” öyküsünde anlatıc1, bilgisini karakterle eşitler ve henüz kendi ses tonu okur tarafından duyulmamışken "serbest dolaylı anlatım" yordamıyla ilkin karakterin iç sesinin duyulmasına izin verir: "Ki buna insan demişler!" (Dikkat! Klasik öykü geleneğinde karakter sesi fizikselken bu metinde iç sese dönüşür.) Öyküde ilki dışındaki tüm kullanımlarda, sesin kime ait olduğunu ifade etmek için karakter sesinin hemen ardına iliştirilen anlatıcı sesiyle düzey farklılığı okura anımsatılır. Örneğin “Tek bir gece deliksiz bir uyku uyuyabilsem!" karakter söyleminden sonra hangi ruh durumu içinde bu sözün söylendiğini betimlemek için öykü dışı düzeyde "Böyle inildeyip durması şaşırtıcıydı." ifadesi eklenir.

Tıkaçların ilk kez denendiği sahnede karakterin bilincine çekildiğimizi, anlatısallık değil artık öyküsellik alanında bulunduğumuzu düşünürüz. Anlatıda açığa çıkan ve öykü boyunca varlığını koruyan durum, okur-karakter mesafesinin sıfıra indirilmesidir. Uzamsal aralığın daraltılması, seçilen anlatıcı tipi ve ona eşlik eden "sabit odaklanma" sayesinde gerçekleştirilmiştir. Örneğin paragrafın başında beliren "Saate baktı." anlatıcı sesi, gecikmeksizin yerini odaklanmaya bırakır: "Her sabah uyanmaya alışık olduğu bir saat." Belli bir mesafeden karakteri kollayan okur, birdenbire onun bilincine yuvarlanir.

Bu anlatıcı tipi Dorrit Cohn'un (2008) tanımladığ1 "özerk monolog" ile hepten aradan çekilerek okuru, bir paragraf ya da bir kısım boyunca karakterin iç monoloğuyla baş başa bırakır. $\mathrm{Bu}$ cinsten bir teknikle düzenlenen "Şu sokaktan, bu komşulardan, o arabalardan, araba kornalarından, iri köpeklerin ulumalarından kurtulmak bu denli kolaymış demek!” cümlesiyle başlayan paragrafta kahramanın anlatıcı olduğu sanısı bile uyandırılır. Anlatıcı, editoryal yorum hakkını bu metin özelinde kullanmaz. Bunun yerine karakterin kendine yönelen eleştirisi yorum boşluğunu doldurur. Öykünün sonundaki “Onun bütün yiğitliği bu kadar. Kulak tıkaçlarından sevinmesiz cayabilecek kadar." söyleminden, anlatıcı müdahalesi olmaksızın karakter bağlamında bir ironi yaratıldığını anlarız. Oysa kanonik uygulamada ironi doğrudan dış-anlatıcı üzerinden yapılır. Ömer Seyfettin'de tipografik işaretlerin yardımıyla anlatıcının söylemi ve karakterlerinki karışmasın diye gösterilen özen, modernist Ağaoğlu'nun metninde yerini neredeyse manipülasyona bırakır. Yazar, okura yardım etmek bir yana iki alanın birbirine dolanmasına 
neden olur. Anlatıda karakter sesi boşlukta asılı bırakılır ve sesin kime ait olduğu okur tarafından hemen bilinemediği için geçici bir alımlama sorunu ortaya çıkar.

Özdenören'in (2016) “Çark” anlatısı öyküsellik alanı dışında bulunan kavramsal anlatıcı eliyle aktarılır ama bunun yerine kendi hikâyesini anlatan itirafçı anlatıcı yerleştirilse herhangi bir nüans kaybedilmeyecek gibidir (s. 9-11). Karakterin bunaltısı, iç odaklanma üstünden verildiği için dışanlatıcının göremeyeceği alanlar bu yolla aydınlatılmıştır. Böyle olunca metin özelinde, birinci kişili yerine üçüncü kişili anlatımın seçimi, retorik bir tercih olarak anlam kazanır. Örneğin "Korkar ve titrerdi. Binlerce günden beri sürüp gelen durumun ilk defadır ki bugün değiştiğini sezer gibi oldu ve kalkmadı yatağından." cümlelerini, dil bilgisel değişiklikler yapıp yeniden okuyalım. (Korkar ve titrerdim. Binlerce günden beri sürüp gelen durumun ilk defadır ki bugün değiştiğini sezer gibi oldum ve kalkmadım yatağımdan.) Görüldüğü üzere anlam değişmeden eylemler birinci kişi çekimiyle verilebiliyor. Demek ki bir karakter üstünden sabit odaklanma yeğlendiğinde dış-anlatıcı, karakterin iç dünyasını aktarmakta birinci kişi kadar becerikli olabiliyor. Öyküde dikkati çeken bir başka husus, karakterin söz dağarının neredeyse bütünüyle anlatıcının söylemine egemen olmasıdır. Işık şeridinin kamçıya benzetilmesi, sinsice odaya girivermesi, bir şaşırtmaca olarak karşılanması, korkutucu ve gammaz kuşlar gibi alımlanması; karakterin algıları ve biçem (üslup) seçimleridir.

Örnek çözümlemelerin ardından anlatıcı modeli hakkında genel bir değerlendirme yapmak gereklidir. Yazarlar tarafından ayn tip anlatıcı, klasik evre ile modernist evrede farklı olanaklarla kullanılmıştır. Ömer Seyfettin'de mutlak şekilde bilen anlatıcı, son iki öykücüde sınırlandırılmış bilmeyle ortaya çıar. Türk öykücülüğünün-romancılığının klasik evresinde (1870-1950) yansıtıcı bilinçle anlatan sesin birbirine karışmaması istenirken modernist evrede (1950-1980) -belki okuru uyanık tutmak ereğiyle- seslerin birbirinin üstüne yığılmasına izin verilir. Bu modelin diğerlerine göre her durumdaki üstünlüğü; mesafenin ayarlanabilmesi, karakterin dışarıdan ve içeriden betimlenebilmesi, figürlerin özelliklerinden bağımsız olarak her koşulda okur güveninin garantiye alınabilmesidir.

Ben-anlatıcilı model Buket Uzuner'in (2016) "Stockholm'de Ölüm”, Necati Tosuner'in (2012) "Yalnızlığa Övgü" ile Sevgi Soysal'ın "Tutkulu Perçem" anlatıları üstünden değerlendirilecektir. Tanıklıkla itirafçı olmanın ara bölgesinde kendini kurduğu için ilk öykünün çözümlemesi ertelenecektir. "Yalnızlı̆̆a Övgü"de (Tosuner, 2012, s. 1-5) 1ssızlığının ve sevgisizliğinin sonuna kadar farkında olan erkek karakterin sıkılmaları, umutları, umutsuzlukları ben-anlatıcilı modelle ilk elden aktarılır. Herkes çiftken o yalnızdır. Aynı sokaklardan, aynı yüzlerden bıkmıştır. Ardına bakmadan yaşadığı kenti terk etmeyi ister ama gideceği yerin daha iyi olacağıyla ilgili bir fikri yoktur.

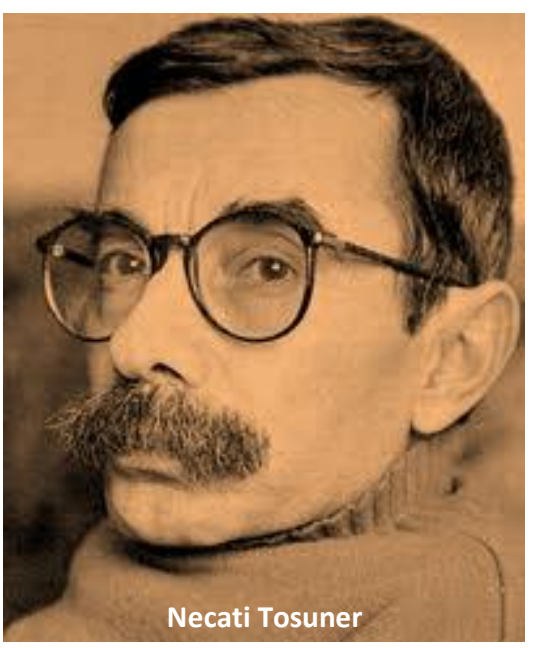
Kendini sıkan şeyi araştırır. Boşluk içindeyken daha iyisini düşler. Mutlu olmak için yalnızlığını sevmesi gerektiğine karar verir. Bütün bu öznel algılar, izlenimler, duygular anlatıcı tercihiyle birlikte anında ve herhangi bir aracıya başvurulmadan okura sunulur. 
Soysal'ın (2016) “Tutkulu Perçem”inde karakterin kent ve öteki algısı herhangi bir filtreye tabi tutulmadan okura aktarılmak istendiğinden ben-anlatıcı modeli yeğlenmiştir (s. 15-16). Üstelik okurun dikkatini dağıtmamak için öyküselliğin merkezine ikinci bir karakter yerleştirilmemiş, aynı zamanda odaklayıcı olan anlatıcının olumsuz izlenimleri, böylece ortaya konabilmiştir. Başkaları tarafından fark edilmediğinden yakınan karakter-anlatıcı, bir hayalet gibi kimselerin dikkatini çekmeden sokakları arşınlar. Özsever oldukları için ilkin öfkesi erkeklere yönelir. Kravatlı ve düğmeliler duyarsız, ceketsizler ise güçsüzdür. Kadraja sonra kadınlar girer, kimlik sorunlarının altı çizilir. Kadın karakter doğrudan değil diğerlerinin algıları üzerinden kendini betimler. Başka bir ifadeyle ben-anlatıcı, okur önünde kendilik imgesini oluşturmak için aynalama tekniğini kullanır. İtirafçının gidişli gelişli bir cadde, üç beş vitrin, devam eden inşaatlar ve parti merkezleri üstünden betimlediği kentin sıkıcı bir yer olduğu hissettirilir.

Uzuner'in (2016), Thomas Mann'ın başyapıtı Venedik'te Ölüm novellasına gönderme yaptı̆̆ “Stockholm'de Ölüm" ilginç anlatıcı pratiklerine sahne olur (s. 65-71). Lasse'nin hikâyesi ve portresi daha fazla hacim kaplasa da öyküye anlatıcı da duygu ve düşünceleriyle katılır. Böylece kadın karakter, tuhaf bir şekilde tanıklık ile itirafçılık arasında salınıp durur. Söylemdeki ilginçlik ise deneyimsel anlatıcının varlı̆̆ına karşın birinci kişiden daha çok ikinci kişili anlatımın kullanılmasıdır. Anlatıcı kadın karakter, İsveçli Lasse'yle birlikte bulunsun ya da bulunmasın anlatmada onu, yani ikinci kişiyi muhatap alır. Diğer uygulamalarda, diğer modellerde açık ya da örtük üçüncü kişilere seslenen anlatma konvansiyonu, bu metin özelinde devre dışı bırakılır. Bir bakıma anlatıcı, ortak hikâyelerini -daha çok da Lasse'nin hikâyesini- yine ona anlatıyor gözükür. $\mathrm{Bu}$ yüzden okur, -şiir söyleminin bildirişim modelinde olduğu gibi- iletişim halkasının dışına itilmiş, hikâyeyi bir muhatap olarak değil, kulak misafiri konumuyla dinlemek zorunda bırakılmıştır Daha seyrek olmak üzere anlatıcı, "Hiç tepki vermeden dinliyorum." tümcesinde görüldüğü gibi birinci kişi adılıyla kendine göndermede bulunurken eylem, birlikte yapılmışsa birinci çoğul kişiyi kullanır: bakışıyoruz, tanışıyoruz, gülüşüyoruz vb. (Zamirler üzerinden bilerek yaratılan karmaşa yüzünden -zira Uzuner biçim oyunlarını fazlasıyla sever- gramatikal tipoloji metnin çözümlemesinde tökezler.) Öykünün genişçe bölümünde dil bilgisel manevralar, anlatısallığın sıfır derecesiyle yapılır. Anlatının son kısmı dışında, ne geçmiş ne birleşik zaman kullanıldığından anlatıcının hikâyeyi anlatmayıp ikinci kişiyle konuştuğu sanısı uyandırılır. Elbette bütün kanon dışı pratiklere rağmen bu kısımlarda, "-DI" morfeminin gizilgüç olarak bulunduğu varsayılmalıdır.

Deneyim alanının diğer ortağı, tanık anlatıcının imkânlarını yakından görmek için Uzuner'in melez karakterli anlatısının yanına Yusuf Atılgan ile Sait Faik'ten birer öykü eklenecek ve öncekine göre daha saf bir tanıklık bunlar üzerinden izlenecektir. Atılgan'ın (2010) "Saatların Tıkırtısı"nda tanık anlatıcı bulunmakla birlikte anlattığı hikâyede kapladığı yer ve düşlerin realiteyle yarışması yüzünden klasik öykücülüğümüzdeki örneklerden farklıdır (s. 16-19). Örneğin Halit Ziya'nın (2006) "Penceremin Hikâyesi" öyküsündeki anlatıcı, penceresinden tanık olduğu karşı evde yaşayan dikişçi genç çiftin hikâyesini, Halide Edip'in (1981) "Kabak Çekirdekçi" öyküsündeki anlatıcı, uzaktan yaptığı gözleme yeğeninden edindiği bilgileri de ekleyerek İsmail Hakkı Bey'in trajik hikâyesini aktarır. Oysa bu metinde, anlatılanlara fazlasıyla kendi duygu ve düşüncelerini 
bulaştıran bir anlatıcı iş başındadır. Öykünün asıl konusu, şehirdeki saat tamircisi olmakla birlikte tanık, yakın plana girmeden onu uzaktan gözetlemekle yetinir. Ayrıca karakterin hayatını araştırmak yerine kendi öznel algılarıyla bir saatçi portresi çizer. Yaptığı en cesur girişim, camına burnunu dayayıp kısa süreliğine saatçiyi izlemektir. Hikâyesini yazmayı istediği hâlde yalan söyleyebilir kaygısıyla onunla konuşmaz. Güvenilir bulmadığı için bakkalla görüşmeyi elinin tersiyle iter. Tabelacı ve aşçı da elendikten sonra aşçı çırağıyla saatçi hakkında kısa bir konuşma yapılır. Geriye yalnızca tanığın düşleri kalır. Beceremeyeceğini düşünüp onun hikâyesini yazmaktan vazgeçtiğindeyse aslında öykü handiyse tamamlanmıştır.

Tanığın duygularının ve özlemlerinin, anlattı̆̆ı hikâyeye karışması Sait Faik'te (1987) de görülür. "Ketenhelvacı" bu soydan bir öyküdür (s. 13-16). Ancak bunun öncekinden fark1, düşsellikle yetinilmeyip bir çeşit röportaj tekniği kullanılarak kahramanla ve ikincil bir karakterle de görüşülmesidir. Anlatıcı ilkin keten helvacılıktan söz eder, ardından meslek ve meslek adamı üstüne düşünür.

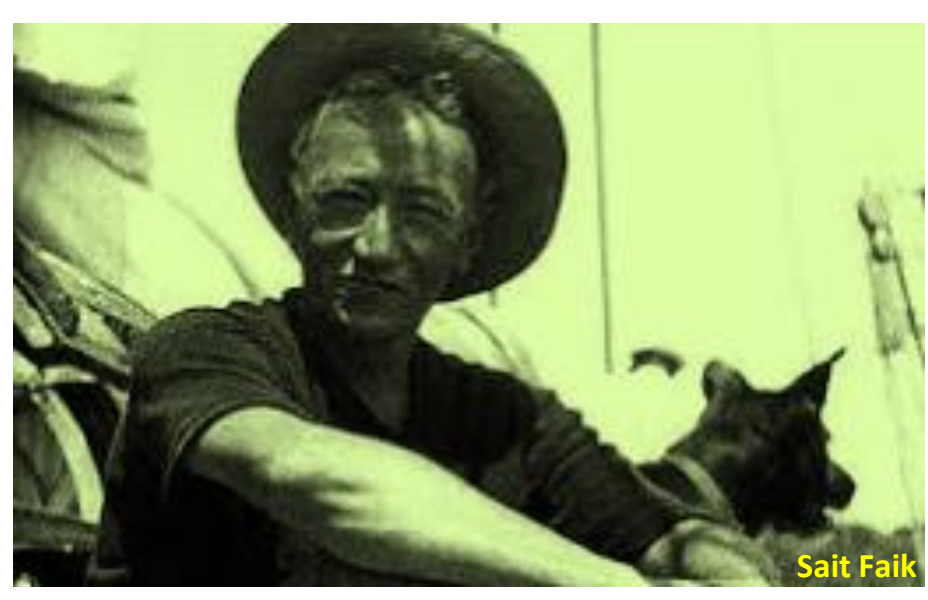
Kestaneciden kahramanı hakkında kimi bilgiler edinir. Helvacı uzaktan göründüğünde ayrıntılı bir fiziki portresini yapar ve onunla iletişime geçerek hikâyesini kendinden dinler. Son olarak metnin başında masal yaratığı şeklinde tanımladığ köyden yolcu eder.

Şimdi iç-anlatıcılı konum, öteki ifadeyle deneyimsel anlatıcı modelinin olanakları topluca değerlendirilecektir. Örneklemeler sırasında görüldügü üzere ben-anlatıcı tipi, okuru iç dünyaya çekebilmekte, karakterin bütün deneyimleri eş zamanlı olarak okura aktarılabilmektedir. Ayrıca değerler eşleşmesi gerçekleştiğinde okur-karakter özdeşleşmesi hızlıca sağlanmaktadır. Sakıncalı yanı ise Soysal'da rastlanan "aykırı" tipler söz konusu olduğunda duygudaşlık etmenin zorluğudur. Bununla birlikte şu saptama rahatlıkla yapılabilir: Okurun ötekine tahammül göstermesi ve onu anlamaya çalışması için modernist anlatıların, bile isteye bu tür durumları yarattıklarıdır. Bütün bu içten bakışa, okur-karakter yakınlaşmasına karşın meşruiyetini Wayne C. Booth'tan (2012) alan soru, bu tür anlatıcıların ne kadar "güvenilir" olduklarıdır. Buna eklenmesi gereken bir başka husus, bu tipin okurdan bir şeyler saklayıp saklamadığıdır. Soysal'ın anlatıcısının kent imgesine güvenilebilir mi? Tosuner'in anlatıcısının bilip bizden gizlediği ayrıntılar nelerdir? Uzuner'in anlatıcısı, merkezî iki karakter arasında yaşanan duygunun adını koymakta niçin ayak sürümektedir?

Yine deneyim alanında yer alan tanık anlatıcı ise okur açısından görece daha güvenilirdir. Zira kendisininkini değil, gözlemini yaptığı karakterin hikâyesini anlatmaktadır. Bu dolaylama sayesinde bilgiler bir filtreden geçmektedir. Ayrıca olaylar bizzat tanıklık üstünden iletiliyor duygusu yaratılmaktadır. Tarihsel okur bakımından bu durumun çifte anlamı vardır: İnsan dünyasında birinci elden tanıklık her zaman önemsenir ve bu formda gerçek masal anlatıcısından 
arketipsel izler bulunur. Klasik öykülerde tanığın yalnızca varlığı bile okurda belli bir güven duygusu yaratırken modernist öykülerde, örneğin Atılgan'ın anlatıcısında bu nitelik aşındırılır. Evet, ilgili anlatıda tanık anlatıcının işaret ettiği bir saatçi var olmasına vardır ama portresinin yapımında kullanılan yağlı boyanın ne kadarının "gerçek", ne kadarının düşsel olduğu bilinemez. Belki bu noktada yeni bir araştırma için şu ön-varsayım dillendirilebilir: Klasiğin tanık anlatıcısı yeni dönemle birlikte evrim geçirmiş; deneyim alanını paylaşan iki anlatıcı tipi, ben-anlatıcılı konumun çıkarına olmak üzere birbiriyle kaynaşma sürecine girmiştir.

\section{SONUÇ}

Anlatının gerçekleşme koşulu olan anlatıcı olgusunun fiziksel sesten imgesele geçişi, kültür alanında ortaya çıkan büyük değişimlerle yakından ilgilidir. İnsan iletişimi için fiziksel dil öncel ve temel olmakla birlikte yazının bulunuşu ve matbaanın icadıyla başka cinsten iletişim olanakları doğmuştur. İşte anlatıcının imgeleşmesini bu kültür devriminin doğal sonucu olarak görmek gerekir. Anlatıcı bağlamında olgusal, kavramsal ve terminolojik değişimlerin art planındaysa tarihsellik içinde farklılaşan "dünya resmi”, felsefi düşünceler ve dünyayı algılama şekilleri bulunmaktadır. Bunlar aynı zamanda mutlak anlatıcıdan öznele, "güvenilir"den "güvenilmez anlatıcı"ya giden yolun momentini oluşturur. Kurmacada dışarıdan anlatılan bireyin yerini, kendini anlatan hatta bizzat bilincini okura sunan öznenin alması aynı sebeple açıklanmalıdır.

Anlatıbilim alanındaki terminolojik yenilenmenin de kavramsal devinimle koşutluk oluşturduğu gözden ırak tutulmamalıdır. Aksi durumda bu yapılanın eski köye yeni âdet getirmek ya da entelektüel "züppelik" olduğu sanılabilir. İlkin her çağın ruhuyla birlikte estetik olgulara yaklaşım farklılaşmakta, buna bağlı olarak kavramsal betimlemeler yenilenmektedir. Retrospektif karakter taşıyan anlatı kuramı bu noktada işe soyunmakta, yeni olguları kavramlaştırıp terim alanını tazelemektedir.

Bu düşünümün sonunda ulaşılan yargı, anlatıcı paradigmalarının değişiminin gerisindeki ilk dinamiğin tarihsellik olduğudur. Kat edilen zaman içinde estetik yordam evrilmiş; bu kültürel edimi okumak/anlamak isteyen kuram, repertuvarını gözden geçirmek zorunda kalmıştır. Paradigma çeşitliliğinin ikinci dinamiğini ise birbirinden farklılaşan kuramsal yaklaşımlar oluşturmaktadır. Belli bir dönem içinde patlak veren anlatıbilimsel anlayışlar bu şekilde açıklanabilir. Zira betimlenen olgularda yeni bir nüans bulan ve aynı olguları, sağduyu tarafından kabul edilebilir gerekçelerle yeniden kavramlaştıran bilince yeni bir terminoloji gerekecektir. 


\section{KAYNAKÇA}

Abasıyanık, Sait Faik (1987). “Ketenhelvacı". Tüneldeki Çocuk/Mahkeme Kapısı (6. basım). Ankara: Bilgi Yayınevi.

Adıvar, Halide Edip (1981). “Kabak Çekirdekçi”. Dă̆a Çıkan Kurt. İstanbul: Remzi Kitabevi. Ağaoğlu, Adalet (2012). Bir Düğün Gecesi. İstanbul: Türkiye İş Bankası Yayınları. Ağaoğlu, Adalet (2015). “Kulaç T1kaçları”. Sessizliğin İlk Sesi. İstanbul: Everest Yayınları. Aktaş, Şerif (2000). Roman Sanatı ve Roman Incelemesine Giriş. Ankara: Akçağ Yayınları.

Atılgan, Yusuf (2010). “Saatların T1kırtısı”. Bütün Öyküler (7. basım). İstanbul: Yapı Kredi Yayınları. Booth, Wayne C. (2012). Kurmacanın Retoriği. Bülent O. Doğan (Çev.). İstanbul: Metis Yayınları.

Cohn, Dorrit (2008). Şeffaf Zihinler: Kurmaca Eserlerde Bilincin Sunumu. İstanbul: Metis Yayınları. Çetin, Nurullah (2007). Roman Çözümleme Yöntemi. Ankara: Öncü Kitap.

Genette, Gérard (2011). Anlatının Söylemi: Yöntem Hakkında Bir Deneme. Ferit Burak Aydar (Çev.). İstanbul: Boğaziçi Üniversitesi Yayınevi.

İleri, Selim (2015). Cumartesi Yalnızh $\breve{g} ı$ (6. basım). İstanbul: Everest Yayınları.

Ömer Seyfettin (1992). "Bomba”. Bomba. Ankara: Bilgi Yayınevi.

Özdenören, Rasim (2016). “Çark”. Hastalar ve Işıklar (10. basım). İstanbul: İz Yayıncılık.

Pamuk, Orhan (1996). Sessiz Ev (16. basım). İstanbul: İletişim Yayınları.

Soysal, Sevgi (2016). “Tutkulu Perçem”. Tutkulu Perçem (6. basım). İstanbul: İletişim Yayınları.

Tekin, Mehmet (2002). Roman Sanatı 1 (Romanın Unsurları). İstanbul: Ötüken Neşriyat.

Tosun, Necip (2017). Emanet Hikâyeler. İstanbul: Dedalus Kitap.

Tosuner, Necati (2012). “Yalnızlığa Övgü”. Özgürlük Masalı (5. basım). İstanbul: Türkiye İş Bankası Yayınları.

Uşaklıgil, Halit Ziya (2006). "Penceremin Hikâyesi”. Solgun Demet. İstanbul: Özgür Yayınları.

Uzuner, Buket (2016). "Stockholm'de Ölüm”. Benim Adım Mayıs (17. basım). İstanbul: Everest Yayınları.

Wood, James (2013). Kurmaca Nasıl İşler. Erkin Bodur (Çev.). İstanbul: Ayrıntı Yayınları.

Yivli, Oktay (2016a). “Anlatıcı ve Perspektifte Yeni Bir Sınıflandırma Girişimi”. II. Uluslararası Türk Kültürü Araştırmaları Sempozyumu Bildirileri. Nevşehir: Hacı Bektaş Veli Üniversitesi. s. 495500.

Yivli, Oktay (2016b). "Sözde Anlatıcı". Uluslararası Türk Dünyası Eğitim Bilimleri ve Sosyal Bilimler Kongresi Bildirileri III. Cilt. Ankara. s. 495-501.

Yivli, Oktay (2017). “Yiğit Bener'den Böcek Öyküleri”. Türük. 11: 68-76.

Yivli, Oktay (2019). Öykü Nasıl Okunur: Modern Öykü ve Yöntem. Ankara: Günce Yayınları. 


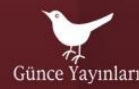

Prof. Dr. Önder Göçgün

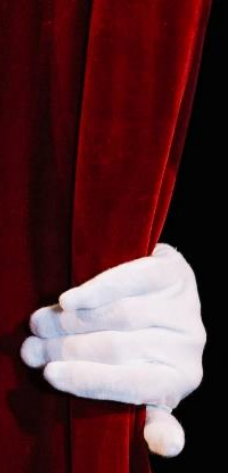

TIYYATRO DENEN HAYAT

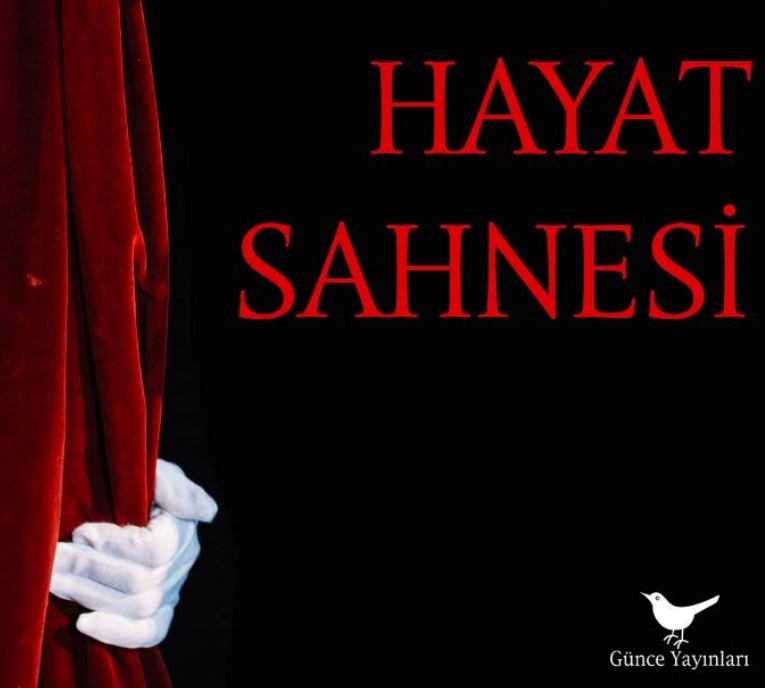

MUIIARREM DAYANC OKTAY YIVLI MACI'I BALIK MAIIMU'I BABACAN SLVIM SLERMEI
YASFMIN MUMCU BLDI் KOÇАKOĞLU NILÜLLLR ILLHAN MAKSUT YIĞITBAS SLL $\triangle M I I L \Lambda N$

\section{EDEBIYATINDA

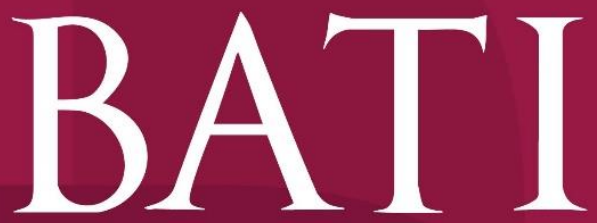 \\ EDEBIYATINDA
AKIMLAR \\ $\underset{\substack{\text { EDEBIYATINDA } \\ \text { AKIMLAR }}}{\mathrm{B} A T \mathrm{~T}}$}

editör

OKTAY YIVLI

HATICE FIRAT

YASEMIN MUMCU

OKTAY YIVLI

OĞUZHAN KARABURGU

BERNA AKYÜZ SIZGEN

NILÜFER ILHAN
ÜMMÜHAN TOPÇU

SEFA YÜCE

HANIFI ASLAN

METIN AKYÜZ

MEHMET SÜMER
YAKUP ÖZTÜRK
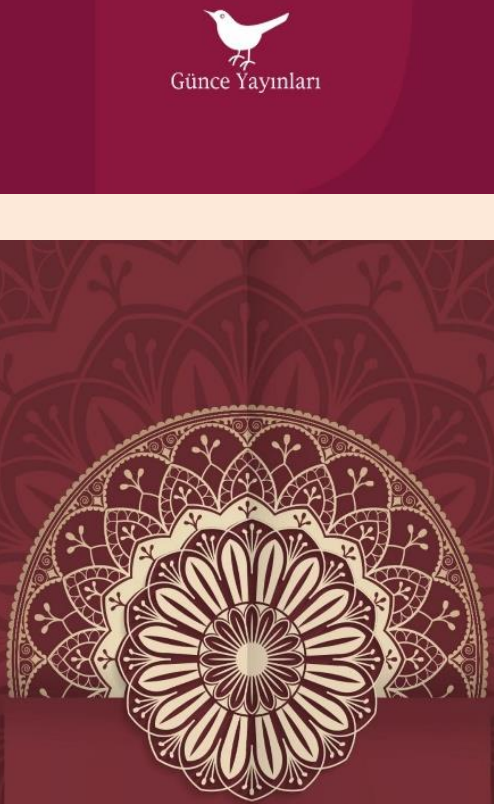

PROF. DR. ÖNDER GÖÇGÜN

$$
\begin{gathered}
\text { Türk } \\
\text { Tasavvuf } \\
\text { Siini }
\end{gathered}
$$

AÇIKLAMALI VE YORUMLU ÖRNEKLERLE 